\title{
The Neglected Potential of Rothbard's Preface to Theory and History as an Introductory Text on Austrian Methodology
}

George PickeringI (100000-0002-6075-4184

University of Oxford, Oxford, Oxfordshire, United Kingdom

\begin{abstract}
Given the breadth of the ideas of the Austrian School of Economics and the numerous lengthy treatises across which those ideas are scattered, it is difficult to recommend an introductory text that conveys its definingcharacteristics. However, in this regard, Murray N. Rothbard's rarely discussed Preface to Ludwig von Mises's book Theory and History possesses considerable untapped potential. The Preface's merits as an introductory reading stem not only from its persuasive summary of the praxeological method and the core arguments in its favor, amongst other distinguishing characteristics of the Austrian School, but also from its brevity and Rothbard's stylistic clarity, which make it incredibly accessible to newcomers to Austrian ideas.
\end{abstract}

Keywords: Murray N. Rothbard, praxeology, Austrian Economics, methodology, epistemology.

\footnotetext{
I George Pickering is a doctoral student of Economic History at the University of Oxford. He received his undergraduate degree from the London School of Economics, and was a Research Fellow at the Ludwig von Mises Institute in 2017 and 2018. His research interests include monetary history and the history of economic methodology. E-mail: georgepickering@googlemail.com
} 


\section{El potencial desatendido del Prefacio de Rothbard a Teoría e historia como texto introductorio de la metodología austriaca}

Resumen: Dada la amplitud de las ideas de la Escuela Austriaca de Economía y los numerosos y extensos tratados en los que se encuentran distribuidas, no es tarea fácil recomendar un texto introductorio que transmita de forma clara y rápida las características definitivas de esta escuela de pensamiento. Sin embargo, el Prefacio del libro de Ludwig von Mises, Teoría e historia, donde apenas se habla de Murray N. Rothbard, posee un potencial considerable sin explotar en este sentido. Los méritos del Prefacio como lectura introductoria se derivan no solo de su persuasivo resumen del método praxeológico y los argumentos centrales a su favor, entre otras características distintivas de la Escuela Austriaca, sino también de su brevedad y la claridad estilística de Rothbard, que lo hacen particularmente accesible para los que recién están conociendo las ideas austriacas.

Palabras-clave: Murray N. Rothbard, Praxeologia, Economia Austríaca, Metodología, Epistemología.

\section{O potencial inexplorado do prefácio de Rothbard à obra Teoria e história como texto introdutório à metodologia austríaca}

Resumo: Dada à amplitude das ideias da Escola Austríaca de Economia, e os numerosos e extensos tratados em que elas estão distribuídas, não é fácil recomendar um texto introdutório que transmita de forma clara e rápida as características definitivas dessa escola de pensamento. No entanto, o prefácio de Rothbard à obra Teoria e história, de Ludwig von Mises, tem um grande potencial nesse sentido. Os méritos desse prefácio como leitura obrigatória derivam não só de seu resumo persuasivo do método praxiológico e dos argumentos centrais em sua defesa, entre outras características distintivas da Escola Austríaca, mas também pela brevidade e clareza estilística de Rothbard, que o tornam particularmente acessível às pessoas interessadas em conhecer as ideias austríacas.

Palavras-chave: Murray N. Rothbard, Praxeologia, Economia Austríaca, Metodologia, Epistemologia. 


\section{Introduction}

Any school of thought that wishes to spread its ideas to new readers and new generations must grapple with the tricky question of which introductory readings recommend to interested newcomers and upon which criteria to make this decision. The difficulty of the decision is compounded in the Austrian School's case given its nearly 150-year history. During this time, various topics, perspectives, and approaches have been set forth by the diverse thinkers in this tradition. Furthermore, many of the works widely regarded as the key texts of the Austrian tradition take the form of thousand-page treatises that we cannot expect newcomers to approach with enthusiasm.

In choosing which works to recommend for introductory purposes, one must first determine which ideas, elements, or characteristics define this school of thought. The case of the Austrian School is particularly tricky, given its distinctiveness from the mainstream of contemporary economic thought. The Austrian School is characterized by several important qualities which have distinguished it from the mainstream of economic thought at various points throughout its history: its subjectivist ordinal theory of value (MENGER, 2007 [1871], p. 114-174); its emphasis on methodological individualism (MISES, 1998 [1949], p. 41-44); its writings on money, central banking, and the business cycle (MISES, 2009 [1912]; HAYEK 1933 [1929]); and the pro-market orientation of most of its exponents (MCCAFFREY, 2016). However, arguably the most significant defining characteristic of modern Austrian Economics is the so-called praxeological method. This particular significance stems both from its central importance to the Misesian wing of the Austrian School, and from its profound divergence from the mainstream methodological approach.

It is undoubtedly true that several reasonable objections could be made against this identification of the praxeological method as one of the most essential defining-characteristics of Austrian Economics. After all, the Austrian School had been in existence for almost 60 years before Ludwig von Mises began developing his methodological system (MISES, 2003 [1933]). However, he regarded his efforts as, in large part, as an attempt to systematize the methodological approach which had been taken for granted by previous generations of Austrian economists (HÜLSMANN, 2007, p. 664-674). Even amongst Austrians, the merits of Mises's praxeological method and broader methodological framework are not accepted as noncontroversial (CALDWELL, 1998, p. 118). However, given the importance of the praxeological method to the Misesian branch of the Austrian tradition, not to mention the extent to which praxeology is, rightly or wrongly, associated with the Austrian School as a whole in the minds of many mainstream onlookers (MEARMAN, 2012), this distinctive method is certainly one of the key elements of the Austrian approach with which newcomers should familiarise themselves.

Thankfully, the Austrian School has produced several works in favor of the praxeological method, many of which could be recommended as introductions to the topic, depending on the number of pages and the density of language that the individual reader is willing to bear. These potential introductions to praxeology range from whole books (MISES, 2007 [1957]), to 
sections of longer works (MISES, 1998 [1949], p. 1-91; ROTHBARD, 2011, p. 1-136), to shorter monographs (MISES, 1962; HOPPE, 1995), to individual academic articles (ROTHBARD, 1957; ROTHBARD, 1960; ROTHBARD, 1976).

However, one piece rarely mentioned in discussions of introductory texts on Austrian methodology, despite its great potential in that regard, is Murray N. Rothbard's Preface to Mises's methodological masterwork Theory and History (ROTHBARD, 2007 [1985]). Writing the Preface for Mises's great methodological work allowed Rothbard to set down his perspective on the importance of the praxeological method and the key arguments in its favor, in perhaps the most succinct presentation of his career. Indeed, with less than 2,000 words, its sheer brevity represents one of its most significant advantages over the other potential introductory texts cited above. Its value is further enhanced by Rothbard's characteristically accessible and clear writing style. Besides presenting the fundamentals of praxeology and the core arguments in its favor, Rothbard also invites the novice reader into the territory of broader meta-economic questions and even touches on his divergence from Mises on the aprioristic nature of the action axiom.

The Preface admittedly was not attempting to significantly advance the state of knowledge on Austrian methodology or offer any groundbreaking new insights. Much of what Rothbard presents is more fully elaborated in his various methodological articles (ROTHBARD, 2011, p. 1-136). However, the fact that a significant Austrian thinker such as Rothbard was able to present the case for the praxeological method in such a compelling and accessible manner, in a space scarcely longer than the average newspaper editorial, sets this Preface apart as a potential introductory reading to newcomers to Austrian ideas.

\section{Praxeology as the Core of Austrian Economics}

The final sentence of Rothbard's Preface to Theory and History contains what may as well have been its title: "Without praxeology no economics can be truly Austrian" (ROTHBARD, 2007 [1985], p. 19). This identification of the praxeological method as what it means to be Austrian, in the opening of a book on Austrian methodology, marks Rothbard's Preface as a valuable and highly-focused introductory text on the Austrian School.

Indeed, this point is perhaps even more essential to understanding Austrian Economics in our own time than when Rothbard wrote the Preface, which first appeared in the Mises Institute's 1985 reprint of Theory and History. Although Austrian Economics could by no means be described as part of the current mainstream of economic thought, it is also no longer suffering through the true wilderness period it endured throughout most of Rothbard's own life. Awareness and intelligent discussion of Austrian ideas are no longer utterly unheard of in economics departments. Many market-sympathetic mainstream economists today consider themselves somewhat influenced by Austrian, or at least Hayekian, ideas (SKARBEK, 2008), while particular fields of modern economics, such as entrepreneurship, exhibit a strong Austrian presence (FOSS et al., 2019; BYLUND; MCCAFFREY, 2017). 
This is certainly a welcome development, yet it should nevertheless provoke a certain healthy trepidation amongst Austrians as these ideas are adopted (and adapted) by others. Without the firm foundation of the praxeological method, the source of these theories' persuasiveness, clarity, and internal consistency may become obscured as they undergo piecemeal reinterpretation by mainstream free marketeers. Consequently, a front-andcenter identification of the praxeological method as one of the most indispensable, defining characteristics of Austrian Economics is now arguably even more vital than it was at the time of Rothbard's writing. After all, Rothbard notes that "adherence to the free market ... is now not uncommon among economists (albeit not with Mises's unerring consistency), but few are ready to adopt the characteristically Austrian [praxeological] method" (ROTHBARD, 2007 [1985], p. 13), and this correlation between muddled methodology and faltering support for free markets is no coincidence.

\section{Methodological Dualism and 'Directions' of Scientific Investigation}

After a brief introduction establishing the context and importance of Mises' Theory and History, the first aspect of Austrian methodology Rothbard emphasizes is the concept of methodological dualism. This is "the crucial insight that human beings must be considered and analyzed in a way and with a methodology that differs radically from the analysis of stones, planets, atoms, or molecules" (ROTHBARD, 2007 [1985], p. 13).

It is easy to understand how novice Austrians might be tempted to rush straight past this sort of abstract, methodological point, in favor of the School's more engaging and applicable theories on business cycles or interventionism. However, a correct and fully-understood grasp of methodological dualism is an essential first step if one wishes to gain a proper understanding of the Misesian approach to economics and the social sciences in general. Without this, the Misesian insistence on a purely logical-deductive method would be viewed as an inconvenient eccentricity, standing in the way of the career-advancing merits of statistical and econometric research.

Rothbard lays out several arguments in favor of methodological dualism, including the fundamental point that human beings, unlike mere physical matter, have the capacity to choose, change their values, and alter their courses of action, rather than exclusively being controlled by measurable external forces. He also summarises the fundamental argument which he had elaborated more fully in his methodological articles (ROTHBARD, 1957) - that the natural sciences and economics operate with opposite 'directions' of scientific investigation.

In the natural sciences, what is visible and easily measurable are the final outcomes resulting from the interactions of the underlying laws and forces. In contrast, those laws and forces themselves are not self-evident. Therefore it makes sense for the natural scientist to observe and collect data about those empirical phenomena, and then tentatively work their way back toward a description of the underlying forces at play. For example, a physicist cannot directly observe or intuitively know the precise nature of the Universal Law of Gravitation on an experiential level. However, they can empirically observe the movements of objects under 
the effects of gravity, present an explanatory hypothesis, and then use laboratory experiments to test whether or not observed facts falsify that hypothesis.

Economists and other scientists of human action, however, are in precisely the opposite situation: the fundamental laws of human action are self-evident, axiomatic, and can be known with apodictic certainty, whereas the causes of particular real-world events cannot be directly known, measured, or isolated (ROTHBARD, 1957, p. 315). Suppose the number of oil barrels sold by a particular oil company falls from one month to the next, for example. In that case, this historical event will inevitably be the complex result of many factors. The economist cannot directly observe which different factors and laws contributed to that outcome, or to what extent, nor could they possibly find out by repeating the process in laboratory conditions and holding different variables constant. However, the economist can deduce, from self-evident facts of human action, the law that, other things being equal, people will demand more units of a good at a lower price than at a higher price. Therefore, it can be said with apodictic certainty that, other things being equal, the number of barrels sold by the oil company would have been greater (or at least equal) if the price had been lower. In other words, rather than starting with empirical facts and then grasping backward toward theories, economists start with the self-evident and axiomatic "fact that human beings have goals and purposes and act to attain them" (ROTHBARD, 2007 [1985], p. 25-26), from which they can then logically deduce increasingly precise and applicable theories.

Contrary to some criticisms of the praxeological method, this does not mean that praxeology is a science entirely detached from and unconcerned with empirical reality. Unlike certain other aprioristic economists such as Frank Knight, Mises did not regard pure economic theory as studying "a constructed realm that bore little resemblance to the real world" (EMMETT, 2009, p. 75-76). Instead, praxeology is a logical deductive science focussed squarely on the task of explaining the economic relations of the real world, with its fundamental axioms being both knowable a priori, in Mises's view, and accurate descriptions of undeniable truths of real human behavior (LEESON; BOETTKE, 2006, p. 256). Furthermore, Austrian economists do not deny that empirical data often plays a role in informing the actions of economic agents in the real world, making it a suitable subject for analysis by economic theory: for example, the influence on the purchasing power of money by consumers' and entrepreneurs' reactions to the array of price data from the recent past (PICKERING, 2019, p. 605).

These two arguments presented by Rothbard - that human beings are to some extent self-directed and can change their values and courses of action, thus making each particular historical case of human action radically heterogeneous, incommensurable, and impossible to repeat in laboratory conditions; and that economics has a fundamentally different 'direction' of scientific investigation than the natural sciences - combine to strongly make the case that applying the empirical-inductive method of the natural sciences to economics is not only unnecessary and fruitless, but, on a fundamental level, does not even make sense. 


\section{How Should Theory and History Interact?}

This aspect of Rothbard's Preface touches on a point of broader significance, especially for those engaged in the study of economic history, a field to which the upcoming generation of Austrians have increasingly been drawn due to its relatively less hostile intellectual climate (see for example NEWMAN, 2019; ROUANET 2019; CALTON, 2018; HANSEN, 2018; PICKERING, 2018). If history has unique and radically heterogeneous events from which economic theory can draw no lessons, how, if at all, can non-contingent theory and contingent history be meaningfully brought together? In other words, what is the point of Economic History, and what should economic historians actually be doing? This is a question for which the Austrian approach provides a convincing answer, while the mainstream approach is arguably not only wrong but internally self-contradictory.

Rothbard's Preface highlights time and again how "each historical event is a complex, unique resultant of many causal factors" (ROTHBARD, 2007 [1985], p. 27). However, his emphasis on this point is not intended to draw a wall of separation between theory and history, but rather to stress that historical events cannot be homogenized and quantified in a way that we could infer valid theoretical insights from them. On the contrary, it is "the complex historical event itself [that] needs to be explained by various theories" (ROTHBARD, 2007 [1985], p. 28). It is the role of the economic historian to apply pure economic theory to the task of explaining the causal forces at work behind the events of history, which cannot themselves be directly observed. This is a crucial function in the case of events long passed, but perhaps even more so to those investigating 'history' in the Misesian definition, which includes all events occurring before this exact moment, including the very recent history would typically be called current events.

This sort of clear and explicit definition of the role and significance of Economic History is mostly absent from the mainstream approaches to that subject. After all, many mainstream economists are well aware of the difficulties and limitations of constructing hypothetical theories from the cacophonous data of empirical reality, which leaves them still timider in their attempts to apply that theory to explain the events of history.

However, arguably the problem for mainstream economic historians runs deeper still. If one subscribes to the mainstream view that it is from the data of history that economic theory must first be derived, it is difficult to turn around and use that same theory to explain the events of history without becoming dizzy from the circularity of it all. This tricky impediment to applying mainstream economic theory to explain the causal forces behind historical events is rarely explicitly acknowledged. However, it is nevertheless apparent in the highly qualified and often inconclusive findings so often produced in the field of economic history. Indeed, if deprived of the use of economic theory to explain the facts of history, economic historians are not only reduced to mere chroniclers of dry facts, unable to explain causation or the broader forces at play, but also deprived of the very tool which would otherwise inform them of which events and factors are even worth chronicling. 


\section{The Fundamental Purpose of Science: Prediction or Explanation?}

Given the brevity of Rothbard's Preface to Theory and History, it is a testament to its considerable potential as an introductory text that it is not only able to summarise the core arguments for the praxeological method, but also to touch on broader, meta-economic questions, such as whether prediction or explanation should be the fundamental purpose of economic science.

This conflict relates closely to the overall themes of the Preface not only due to its importance to Austrian methodology in general, but also due to how closely Positivism is intertwined with the desire to predict future economic outcomes. To make quantitative predictions, the mainstream economist must attempt to find quantitative correlations which can then be extrapolated into the future, which requires "treating individuals not as unique creatures, each with his or her own goals and choices, but as homogenous and therefore predictable bits of 'data'" (ROTHBARD, 2007 [1985], p. 14). However, as Mises emphasized (MISES, 2007 [1957], p. 4-5), this endeavor to homogenize and quantitively analyze human action runs up against an insurmountable obstacle in the fact that human beings choose their courses of action and can change their minds, rather than being exclusively controlled in predictable and invariable ways by measurable external forces. The result of this is that the field of human action lacks any quantitatively constant relations which could be mathematically operated upon with any degree of certainty or epistemological justification.

In the mathematical treatment of Physics, the distinction between constants and variables makes sense; it is essential in every instance of technological computation. In Economics, there are no constant relations between various magnitudes. Consequently, all ascertainable data are variables, or what amounts to the same thing, historical data. The mathematical economists reiterate that the plight of mathematical economics consists in the fact that there are a great number of variables. The truth is that there are only variables and no constants. It is pointless to talk about variables where there are no variables. (MISES, 2007 [1957], p. 11-12, emphasis original.)

There is an array of interests pressuring economists in the direction of prediction rather than explanation, from businesses that believe they could profit from enhanced foresight and political agents wishing to fine-tune their interventions. However, Rothbard's Preface highlights the critical point that, from the Austrian School's perspective, quantitative prediction is neither necessary nor sufficient to define what it means to be scientific in the field of economics. Instead, Austrian Economics aims to understand and explain the logically necessary aspects of human action, via the praxeological method, and hence the causal forces behind economic interactions. Indeed, such understanding and explanation is logically antecedent to any economic predictions one might hope to make, as such predictions must first be based on an understanding of the expected relationship between the magnitudes under consideration. Therefore, far from being an isolated and benign methodological foible, Rothbard's Preface emphasizes that the mainstream's preference for empirical-mathematical analysis is an inevitable corollary of the desire to use economics as a predictive, rather than an explanatory, 
tool. After all, it is no accident that "the original motto of the Econometric Society [was] 'Science is Prediction'” (ROTHBARD, 2007 [1985], p. 14).

\section{Apriorism or 'Broad Empiricism'?}

One topic to which Rothbard devotes a surprising amount of space in this short Preface is his divergence from Mises on whether economics can meaningfully be classified as an $a$ priori discipline. This is a distinction that many more casual followers of the Austrian School may not even be aware of. Even some seasoned Austrians might be surprised at the amount of attention Rothbard pays it in this short, introductory piece.

However, Rothbard, who was well known for his timidity and deference when it came to disagreeing with his mentor publicly, nevertheless went so far as to call Mises's use of the term a priori "idiosyncratic" and unnecessarily confusing (ROTHBARD, 2007 [1985], p. 14). In place of apriorism as the foundation of the action axiom and other underlying principles of economics, Rothbard instead argues that they are based on what he calls broad empiricism and appeals to self-evidence as a legitimate and neglected epistemic justification for such fundamental statements, an argument which he had developed at greater lengths elsewhere (ROTHBARD, 1960).

Is the fact of human purposive action "verifiable"? Is it "empirical"? Yes, but certainly not in the precise or quantitative way that physics's imitators are used to. The empiricism is broad and qualitative, stemming from human experience; it has nothing to do with statistics or historical events. Furthermore, it is dependent on the fact that we are all human beings and can therefore use this knowledge to apply it to others of the same species. Still, less is the axiom of purposive action "falsifiable." Once mentioned and considered, it is so evident that it forms the very marrow of our experience in the world. (ROTHBARD, 2007 [1985], p. 26-27)

Many who are aware of this split between Mises and Rothbard likely view it as a mere terminological difference. However, the fact that Rothbard gives it such a direct and detailed appraisal in this short Preface indicates that he viewed it as a matter of more fundamental importance. While it would be beyond the scope of this article to extensively explore this distinction and develop a firm argument on one side or another, Rothbard's emphasis on this topic nevertheless spotlights an interesting area for further exploration in future Austrian methodological works.

\section{Conclusion}

In addition to being one of the most neglected masterpieces of the Austrian School, Ludwig von Mises's Theory and History (MISES, 2007 [1957]) is arguably the most thoroughly developed single work on the critical topic of Austrian methodology, especially in the Mises Institute's edition that includes Rothbard's Preface. The Preface contextualizes Mises's work and allows Rothbard to summarise its key contributions in his usual clear and accessible style 
while further drawing the reader into broader questions of epistemology and the fundamental purpose of economic science. Furthermore, in summarising the key points of Austrian methodology in such a short preface, Rothbard almost inadvertently produced a piece with significant potential as an assignable reading for either students or interested newcomers to Austrian ideas.

Although several other works could conceivably be recommended as introductions to Austrian Economics (MISES, 1998 [1949], p. 1-91; MISES, 2007 [1957]; MISES, 1962; ROTHBARD, 1957; ROTHBARD, 1960; ROTHBARD, 1976; ROTHBARD, 2011, p. 1-136; HOPPE, 1995), Rothbard's Preface to Theory and History is set apart from these by its sheer brevity and stylistic accessibility, its persuasive case for the praxeological method as one of the most fundamental and definitive characteristics of Austrian Economics, and the broad range of other Austrian themes on which it is able to touch. These factors combined make the Preface particularly suitable as an introductory reading on the Austrian School and its core ideas.

The importance of an early grounding in methodology for budding Austrians is particularly apparent in the methodologically muddled work of many mainstream economists, including free marketeers. If more attention is directed toward the introductory potential of shorter methodological works, such as Rothbard's Preface to Theory and History, we can expect future generations of Austrians to become stronger and more consistent in their methodology, understanding, and advocacy of sound economics in general.

\section{References}

CALDWELL, B. J. Beyond Positivism: Economic Methodology in the Twentieth Century, Revised Edition. London: Routledge, 1994.

CALTON, C. Was the American Civil War a "Civil War"? Mises Institute, 2018. Available at: https://mises.org/ wire/was-american-civil-war-civil-war. Accessed: Jul 102020.

EMMETT, R. B. Frank Knight and the Chicago School in American Economics. London: Routledge, 2009.

FOSS, N. J., P.G. KLEIN, and C. BJØRNSKOV. The Context of Entrepreneurial Judgment: Organizations, Markets, and Institutions. Journal of Management Studies, v. 56, n. 6, 2019.

HANSEN, K. M. Libertarian Class Analysis and Economic History. Unpublished. Available at: http:// østrigskeobservationer.dk/wp-content/uploads/2019/02/Libertarian-Class-Analysis-paper.pdf. Accessed: Jul 102020.

HAYEK, F. A. Monetary Theory and the Trade Cycle. New York: Sentry Press, 1933 [1929].

HOPPE, H. H. Economic Science and the Austrian Method. Auburn: Ludwig von Mises Institute, 1995.

HÜLSMANN, J. G. Mises: The Last Knight of Liberalism. Auburn: Ludwig von Mises Institute, 2007.

LEESON, P. T., and P. J. BOETTKE. Was Mises Right? Review of Social Economy, v. 64, n. 2, 2006.

MCCAFFREY, M. Austrian Economics Is More Than Free-Market Economics. Mises Wire 12th January 2016. Available at: https://mises.org/library/austrian-economics-more-free-market-economics. Accessed: Aug 152020. 
MEARMAN, A. Heterodox Economics and the Problems of Classification. Journal of Economic Methodology, v. 19, n. 4, 2012.

MENGER, C. Principles of Economics. Auburn: Ludwig von Mises Institute, 2007 [1871].

MISES, L. The Theory of Money and Credit. Auburn: Ludwig von Mises Institute, 2009 [1912].

. Epistemological Problems of Economics. Auburn: Ludwig von Mises Institute, 2003 [1933].

. Human Action: A Treatise on Economics. Auburn: Ludwig von Mises Institute, 1998 [1949].

Theory and History: An Interpretation of Social and Economic Evolution. Auburn: Ludwig von Mises Institute, 2007 [1957].

. The Ultimate Foundation of Economic Science: An Essay on Method. Princeton: D. Van Nostrand Company Ltd., 1962.

NEWMAN, P. Personnel is Policy: Regulatory Capture at the Federal Trade Commission, 1914-1929. Journal of Institutional Economics, v. 15, n. 6, 2019

PICKERING, G. The Role of Bank of England Note Issues Amongst the Causes of the Panic of 1825. Unpublished. Available at: https://papers.ssrn.com/sol3/papers.cfm?abstract_id=3208923. Accessed: Jul 102020.

. The Relevance of Bitcoin to the Regression Theorem: A Reply to Luther. The Quarterly Journal of Austrian Economics, v. 22, n. 4, 2019.

ROTHBARD, M. N. In Defense of “Extreme Apriorism”. Southern Economic Journal, v. 23, n. 3, 1957.

. The Mantle of Science. Scientism and Values. Princeton: D. Van Nostrand Company Ltd., 1960.

Praxeology: The Methodology of Austrian Economics. The Foundations of Modern Austrian

Economics. Princeton: D. Van Nostrand Company Ltd., 1976.

. Preface. Theory and History. Auburn: Ludwig von Mises Institute, 2007 [1985].

. Economic Controversies. Auburn: Ludwig von Mises Institute, 2011.

ROUANET, L. The Interest Group Origins of the Bank of France. Public Choice, forthcoming, 2019.

SKARBEK, D. B. F. A. Hayek's Influence on Nobel Prize Winners. The Review of Austrian Economics v. 22, n. 1, 2008.

\section{Acknowledgements}

My thanks to Fernando Monteiro D'Andrea and C. Jay Engel for their comments and encouragement. 